\title{
TOURIST ESCORT AND THE BUSINESS ETHICS ${ }^{* * * *}$
}

This paper deals with the problems related to the development of business ethics and the profession of tourist escort. The starting hypothesis of this research is based on the belief that business ethics in Serbia is not adequately regulated, that tourist escorts are still not properly educated on this issue and that the whole profession is not sufficiently regulated and protected. Historical method, as well as the field research (co-author's work on the position of the tourist escort), together with the survey research, were used for the purpose of data collecting procedure. Analysing the data and interpretation of gained results were conducted by using the descriptive, statistical, comparative and analyticalsynthetic method.

Keywords: tourist escort, Serbia, tourism, business ethics

University of Novi Sad, Faculty of Sciences, Department of Geography, Tourism and Hotel Management; aleksandra.lazarevic77@gmail.com

** University of Novi Sad, Faculty of Sciences, Department of Geography, Tourism and Hotel Management; sadragin@gmail.com

*** Research Associate, University of Novi Sad, Faculty of Sciences, Department of Geography, Tourism and Hotel Management; majamijatov@gmail.com

**** This paper is supported by the Ministry of Education, Science and Technological development (Project OI 176020) and the Autonomous Province of Vojvodina, Provincial Secretariat for Higher Education and Scientific-Research Activity (114-451-2080/2016-01, Program 0201, 2016-2019). 


\section{Introduction}

The word "ethics" derives from the Greek word ethos (custom, essence, spirit) and it is usually considered as a synonym for morality. It is a part of the philosophy that studies and estimates the values, in terms of what is considered as good or bad; what could or should not be done; but it is also a part of the philosophy that considers the origin of morality, together with its principles ${ }^{1}$. Thus, business ethics represents a set of personal and collective moral acts throughout all forms of business activities, focused on determining the boundaries to which is possible to go, in order to provide an avoidance of undesirable relationships within the company and in its environment, caused by those activities, procedures and decisions, as well as avoidance of unnecessary costs and causing the damage to the company itself and to environment where it is operating. Therefore, the precise subject of business ethics is obtained by crossing the moral and economic aspects of the business ${ }^{2}$.

Increased interest in researching business ethics is reflected in an extensive literature devoted to this topic ${ }^{3}$, which is pointing to the fact that the business world is increasingly accepting the importance of business ethics ${ }^{4}$. Some of these $1 \quad$ Subotić Dragan (2009): Korporativna poslovna etika: Vrednosti - načela - modeli (Knjiga 1). Beograd, Primenjena korporativna poslovna etika.

2 Ristić Dušan (2004): Osnovi menadžmenta, Novi Sad, Fakultet za menadžment.

3 Hansen Fred and Smith Michele (2006): 'The ethics of business strategy', Handbook of Business Strategy, 7(1), 201-206;

MacDougall E. Alexandra, Bagdasarov Zhanna, Johnson F. James and Mumford D. Michael (2015): 'Managing workplace ethics: An extended conceptualization of ethical sense making and the facilitative role of human resources', Personnel and Human Resources Management, 33, 121-189;

Miller A. Robert (2014): 'Profiles and shadows in business ethics. Moral saints and moral exemplars', Ethical Issues in Organizations, 10, 97-115;

Robertson J. Christopher and Athanassiou Nicholas (2009): 'Exploring business ethics research in the context of international business', Management Research News, 32(12), 1130-1146;

Serwinek J. Paul (1992): 'Demographic and related differences in ethical views among small businesses', Journal of Business Ethics, 11, 555-566;

Stark Andrew (1992): 'What's the matter with business ethics?' Harvard Business Review, 71 (3), 38-48;

Trevino K. Linda (1992): 'Moral reasoning and business ethics: Implications for research, education and management', Journal of Business Ethics, 11, 445-459;

Warren C. Richard (2011): 'Are we making progress in international business ethics?' Humanomics, 27(3), 212-224.

4 Donaldson Tom (2003): Taking ethics seriously - A mission now more possible, The Academy of Management Review, 28, 363-366;

Elci Meral, Kitapci Hakan and Erturk Alper (2007): 'Effects of quality culture and corporate ethical value on employee work attitudes and job performance in Turkey: An integrative approach', Total Quality Management, 18(3), 285-302; 
studies pointed to a positive effect of business ethics on the organization itself, first of all, in the form of better performances and productivity of the business, which is the reason why ethical behaviour could be considered as useful, because organizations that adhere to moral principles are often more profitable in comparison with those that are prone to unethical practices ${ }^{5}$. Thus, researches from the end of the last century, showed that successful companies, those that mostly neglected the ethical elements in their business, made an average increase of their company's value by $120 \%$ during a ten-year period, while those that implemented these elements in more intensive way increased their company's value for $600 \%$ in the same period. The similar goes with their shares, so the shares of successful "unethical companies" increased for $110 \%$, while "ethical" ones reached the increase in their shares for $900 \%$ throughout the stated period"

The main purpose of studies related to business ethics is an attempt focused on explaining the institutionalization of formal policies and the ways of implementing ethics into a decision-making process and the overall business practice. There is a question in which manner is business ethics incorporated in Serbia in terms of business in the tourism sector?

Elias Z. Rafik (2005): 'The effect of corporate ethics values on accountants' perception of social responsibility', Journal of Applied Business Research, 21(4), 1-10;

Laksmi Rumkumar Lalitha (2004): 'The effect of quality culture and corporate ethics values on intention to leave and organizational commitment', International Journal of Engineering and Management Sciences, 5(2), 140-145;

Sims L. Randi and Keon L. Thomas (1997): 'Ethical work climate as a factor in the development of person-organization fit', Journal of Business Ethics, 16, 1095-1105;

Valentine Sean and Barnett Tim (2002): 'Ethics codes and sales professionals' perceptions of their organizations' ethical values', Journal of Business Ethics, 40(3), 191-200.

5 Weeks A. William, Loe W. Terry, Chonko B. Lawrence and Wakefield Kirk (2004): 'The effect of perceived ethical climate on the search for sales force excellence', Journal of Personal Selling \& Sales Management, 24, 199-214.

$6 \quad$ Hawley, J. (1993): Reawakening the spirit in work: The power of dharmic management. Berrett-Koehler Publishers.

7 Hansen Fred and Smith Michele (2006): 'The ethics of business strategy', Handbook of Business Strategy, 7(1), 201-206;

MacDougall E. Alexandra, Bagdasarov Zhanna, Johnson F. James and Mumford D. Michael (2015): 'Managing workplace ethics: An extended conceptualization of ethical sense making and the facilitative role of human resources', Personnel and Human Resources Management, 33, 121-189;

Robertson J. Christopher and Athanassiou Nicholas (2009): 'Exploring business ethics research in the context of international business', Management Research News, 32(12), 1130-1146;

Smith L. Patricia and Oakley III F. Ellwood (1994): 'A study of the ethical values of metropolitan and nonmetropolitan small business owners', Journal of Small Business Management, 32(4), 17. 


\section{Literature review}

Human resources represent an important factor in tourism business. Therefore, business success of travel agency, as a type of a business organization that is operating within the tourism sector, depends on the quality, qualifications and capabilities of its employees, due to their involvement in creation, selling and providing the tourist services, where tourist escorts have an important role throughout evoking pleasant or unpleasant feelings among the tourists ${ }^{8}$.

An ethical code is the most developed and the most integrated component of managing the business ethics within the business practice of tourism worldwide, which is confirmed by the World Tourism Organization, as a specialized agency of the United Nations ${ }^{9}$, as well as throughout the practice of international hotel chains (e.g, Hilton World Wide, Hyatt, Melia) ${ }^{10}$ and tour operators (e.g. TUI) ${ }^{11}$. It should be noted that system related to managing the business ethics obtains wider issues than simple creation and usage of ethical code, as Trevino and Nelson (1999) pointed out, implementation of the ethical code represents just a beginning of wider ethical efforts. However, even its existence and usage could be considered as an initial and commendable step for further introducing and managing the business ethics, precisely for introducing and managing the ethical business. Different associations in the world, similar to the National Association of Travel Agencies of Serbia, prescribed the code of business and ethical rules that imposes specific requirements, related to professional performing of business tasks and consumers' (tourists') protection, in front of those agencies and tour operators, who want to become their members ${ }^{12}$. The

$\overline{8}$ Štetić Snežana i Dragićević Vanja (2011): 'Evaluacija turističkih agencija u Srbiji', Ekonomske teme, 1, 71-81.

Blešić Ivana, Pivac Tatjana and Besermenji Snežana (2018): 'Croatia as a tourist destination from the perspective of tourists from Serbia', Megatrend revija, 15(1), 19-34.

9 World Tourism Organization - UNWTO. (1999): Global code of ethics for tourism. (Retrived from: http://ethics.unwto.org/sites/all/files/docpdf/serbia.pdf).

10 Krdžić Marko (2014): Poslovna etika na primeru međunarodnog hotelskog lanca "Hilton Worldwide" (master rad), Novi Sad, Univerzitet u Novom Sadu, Prirodno-matematički fakultet, Departman za geografiju, turizam i hotelijerstvo;

Kalinić Mina (2012): Poslovna etika i međunarodni hotelski lanac "Hyatt Hotels Corporation" (master rad), Novi Sad, Univerzitet u Novom Sadu, Prirodno-matematički fakultet, Departman za geografiju, turizam i hotelijerstvo;

Stevanović Sonja (2014): Poslovna etika i međunarodni hotelski lanac "Melia hotels international" (master rad), Novi Sad, Univerzitet u Novom Sadu, Prirodno-matematički fakultet, Departman za geografiju, turizam i hotelijerstvo.

11 Šuleić Marija, Dragin Aleksandra and Dragićević Vanja (2014): 'Business ethics of tour operators - The case study of TUI', Turizam, 18(4), 154-165;

Šuleić Marija, Dragin Aleksandra and Dragićević Vanja (2015): The relationship of a foreign tour operator in Serbia towards tourists based on the example of TUI, 'Turizam', 19(1), 1-12.

12 Simat Karolina, Dragin Aleksandra and Dragićević Vanja (2012): The institutionalization of business ethics of travel agencies in Serbia, 'Turizam', 16(3), 113-123. 
same goes with the principles of managing business ethics within the association of tourist guides ${ }^{13}$. And what about the tourist escorts in Serbia?

During the analysis related to the application of business ethics in tourism, foreign authors often consider the aforementioned ethical code as a vital component for managing the organization and the number of such a researches is constantly increasing ${ }^{14}$, which is pointing to the importance of ethical principles for employees in tourism activities in terms of providing the guidelines for a decision-making process. However, dealing with the issue of ethics in tourism in domestic academic circles is still at its initial level. Academic approaches to this topic were mainly focused on studying ethics in the function of sustainable development of tourism and considering the business ethics within the various managerial subjects, where is usually mentioned as a mechanism for improving the quality of services ${ }^{15}$. Pioneering researches related to ethics in tourism within Serbia were published in this decade ${ }^{16}$, while, according to our findings, this topic was not researched before that period.

13 Prelić Milena (2012): Poslovna etika i turistički vodič (master rad). Novi Sad, Univerzitet u Novom Sadu, Prirodno-matematički fakultet, Departman za geografiju, turizam i hotelijerstvo.

14 Dornier Raphael, Cothias Vanessa and Loussaief Leila (2011): 'The application of collective ethics charters: The case of French Adventure tour-operators', International Business Research, 4(1), 133-144;

Dunfee W. Thomas and Black M. Bruce (1996): 'Ethical issues confronting travel agents', Journal of Business Ethics, 15, 207-217;

Gordon Graham and Townsend Claudia (2001): Tourism: Putting ethics into practice, UK Tearfund, Teddington;

Malloy David Cruise and Fennell A. David (1998): 'Codes of ethics and tourism: An exploratory content analysis', Tourism Management, 19(5), 453-461;

Stevens Betsy (2001). 'Hospitality ethics: Responses from human resource directors and students to seven ethical scenarios', Journal of Business Ethics, 30, 233-242.

15 Kosar Ljiljana i Rašeta Slobodan (2005): Izazovi kvaliteta: Menadžment kvaliteta u hotelijerstvu, Beograd, Viša hotelijerska škola.

16 Dragin Aleksandra, Jovanović Tamara and Besermenji Snežana (2013): Ethical climate in hospitality facilities in Serbia. Paper presented at the 15th Contemporary Trends in Tourism and Hospitality - CTTH 2013, Novi Sad;

Mijatov Maja, Dragin Aleksandra and Jovanović Tamara (2015): Ethical climate in hotels of Kopaonik. Paper presented at the 16th Contemporary Trends in Tourism and Hospitality, Novi Sad;

Mišković Ivana (2012): 'Ethics in providing tourism services by travel agents in Serbia', Turizam, 16(1), 20-28;

Simat Karolina i Dragin Aleksandra (2012): 'Poslovna etika - element uspešnog poslovanja turističkih agencija', Zbornik radova Departmana za geografiju, turizam i hotelijerstvo, 41, 297-309;

Simat Karolina i Dragin Aleksandra (2012): 'Poslovna etika - element uspešnog poslovanja turističkih agencija', Zbornik radova Departmana za geografiju, turizam i hotelijerstvo, 41, 297-309; 


\subsection{Business ethics in the practice of travel agencies in Serbia}

Implementation of ethics and social responsibility in the business of travel agencies in Serbia is based on the rules prescribed within the Law on Tourism, as well as within the YUTA (Serbian National Association of Travel Agencies) standards for member agencies (in the form of aforementioned code), but it should also be based on general conditions of the business, as well as on other accompanying regulations. As business entities, travel agencies also need to operate within the market in accordance with other legislative acts, such as Law on the Protection of Competition, Law on the Consumer Protection, Law on the Prohibition of Discrimination, Law on the Prevention of Abuse, Health and Safety at Work, Law on the Environmental Protection and others ${ }^{17}$. Also, ethical business needs to be reflected in respect of the Code of Business Ethics of the Republic of Serbia ${ }^{18}$, as well as in respect of prescribed contracts between business partners, tour operators, intermediaries, transport companies and, finally, the customers $^{19}$. The existence of numerous specific regulations (primarily the laws) aimed at governing the ethical business in tourism is proof that Serbia recognized the importance of responsible behaviour of employees in tourism ${ }^{20}$. However, there is a question related to sufficiency and adequacy of existing regulations for accepting the importance of ethical business by travel agencies, as important business entities in tourism.

The frequent affairs of travel agencies during the high seasons ${ }^{21}$ are based on unethical business operations and they are indicators that are pointing to insufficient awareness of the main actors within the tourism activity in Serbia regarding the importance of business ethics. These situations could cause inconvenient positions for tourist guides, as representatives of travel agencies, due to their direct interaction with tourists during the travelling. Therefore, this paper will analyse the data obtained throughout the research conducted in the

Šuleić Marija, Dragin Aleksandra and Dragićević Vanja (2014): 'Business ethics of tour operators - The case study of TUI', Turizam, 18(4), 154-165;

Šuleić Marija, Dragin Aleksandra and Dragićević Vanja (2015): The relationship of a foreign tour operator in Serbia towards tourists based on the example of TUI, 'Turizam', 19(1), 1-12.

17 Lazarević Aleksandra (2014): Poslovna etika i turistički pratilac (master rad), Novi Sad, Univerzitet u Novom Sadu, Prirodno-matematički fakultet, Departman za geografiju, turizam i hotelijerstvo.

18 Official Gazette of the Republic of Serbia, 1/2006

19 Simat Karolina, Dragin Aleksandra and Dragićević Vanja (2012): The institutionalization of business ethics of travel agencies in Serbia, 'Turizam', 16(3), 113-123.

20 Dragin S. Aleksandra (2011): Turizam i poslovna etika (materijal sa predavanja), Novi Sad, Univerzitet u Novom Sadu, Prirodno-matematički fakultet, Departman za geografiju, turizam i hotelijerstvo.

${ }^{21} \quad$ Ministry of Trade, Tourism and Telecommunications of Republic of Serbia, 2017 
form of the interviews with Serbian tourist escorts, regarding their attitudes on the business ethics and the extent to which business ethics is represented in the scope of their job requirements.

\subsection{Tourist escort as a profession in Serbia}

Appearance and a definition of the profession of tourist escorts in our country are related to the Law on the Conditions for Providing the Services of Tourist Guides and Tourist Escort from $1978^{22}$, which defined the rights and duties of tourist escorts for the first time, in addition to the profession of tourist guides. According to this Law, services of newly-defined tourist escorts were related to performing the operational and technical activities throughout the following a group of tourists, but also to providing the information to tourists in a situation when the group is not followed by the tourist guide. Immediately in the following year (1979), the Rulebook on the Program and the Manner of checking the Expert Qualifications for the Activities of Tourist Guides and Tourist Escorts for the Territory of the Republic of Serbia (without Federal Autonomous Province) was adopted ${ }^{23}$ and the first professional exam for tourist escorts was organized. Former national tour operator (Yugotours) stimulated development of emitting tourism, so tourist escorts from Serbia were engaged in travelling with domestic tourist groups abroad.

However, due to a decline in tourist arrivals in Serbia in the last decade of the previous century, the term of the tourist escort did not remain in the legal regulations, so the Law on Tourism from 1994 abolished the profession of tourist escorts and put their services to jurisdiction of the tourist guides.

Considering the stagnation of receptive tourism in the mentioned period, but also in the coming years, travel agencies focused their operations towards emitting tourism, which resulted in raising the needs for services of tourist escorts. Thus, The Law on Tourism from $2009^{24}$ extended the term related to "services of tourist professions" to services of tourist guides, tourist escorts, tourist animators and the local tourist guides. Thus, after 15 years, this profession was re-regulated, and in 2010, the Rulebook on the Program and the Method of taking the Professional Exam for the Tourist Escort ${ }^{25}$ was adopted. This Law practically confirmed that tourist guide and tourist escort are not the same professions and it explained the differences between them.

Every year since adopting this Law, a practice of the Ministry is to issue the Call for taking the Professional Exam for the Tourist Escort License. One of the reasons for taking this practice is reflected in a legal obligation faced in front of the

\footnotetext{
22 Official Gazette of the Republic of Serbia, 10/78

23 Official Gazette of the Republic of Serbia, 33/1979

24 Official Gazette of the Republic of Serbia, 36/2009

25 Official Gazette of the Republic of Serbia, 40/10
} 
tour operators regarding the necessity to have licensed tourist escort on their tours with each group and in every transport vehicle. This requirement is in accordance with the aforementioned Law on Tourism that defined the tourist escort as a physical person that follows the tour group and performs different operational and technical tasks from the beginning of the travelling to the destination and back. Thus, a person that performs activities of tourist escort must possess the license issued by the Ministry of the Republic of Serbia, the tourism sector ${ }^{26}$. Also, in respect to this Law, a person that is accompanying the group of tourists within the travel organized by the foreign tour operator, with starting and ending the travel in the foreign country, is not considered as tourist escort.

As part of the elimination tests, candidates need to pass specific tests of psychological ability and foreign language, as well as different professional exams. Successfully passed theoretical part of the exam regarding the foreign language and tests in the field of agency and hotel business, information and guidance services, social system, regulations and tourist policy is a prerequisite for taking the practical part of the exam - guiding the tour in a foreign language. The Ministry issues a certificate as a proof of passed professional exam for the tourist escort, as well as a legitimation and a label mark for each of them.

For example, during the first years (2011 and 2013), 318 out of the total number of 400 candidates, passed the exam and obtained the license of tourist escort ${ }^{27}$. Considering the fact that licensing of tourist escorts in Serbia has been organized recently and that business ethics is not part of theoretical training and practical preparation of candidates for dealing with the mentioned profession, there is a question related to the amount and the manner of implementation and representation of ethics in the work of tourist escorts in our country.

\section{Methodology}

In order to collect as more precise data as possible about the attitudes and representation of business ethics in the work of tourist escorts in Serbia, this research was conducted throughout the interviews. The research was conducted during September of 2014 and the sample obtained ten respondents, precisely ten licensed tourist escorts. During the interviews, respondents answered the 18 questions divided into the three groups: questions regarding the general data of respondents, as well as questions about attitudes of Serbian tourist escorts regarding the business ethics and their work.

As the research was anonymous, the respondents were named as Person 1, Person 2, Person 3 ... Person 10. Their answers will lead to the key results related

26 Law on Tourism, Official Gazette of the Republic of Serbia, 36/2009

27 Dedijer I. (2014): Intervju o licenciranju turističkih pratilaca u Srbiji, Beograd, Ministarstvo trgovine, turizma i telekomunikacija Republike Srbije. 
to the problems that were defined at the beginning of the paper. Although the survey was conducted during the September, when tourist escorts are engaged in a lot amount of work (due to the ending of the summer season and the beginning of the student excursions), they were interested in contributing to the research. Besides the survey research, results are additionally complemented by results gained according to the field research on the basis of the working experience of one of the co-authors within the position of tourist escort.

\section{Results}

The questions asked throughout the interviews were answered by 10 tourist escorts from Serbia, with different gender structure, level of education, vocational qualifications, and the status of the employment and years of working tenure. Nine respondents are female (which is characteristic for the personnel structure in tourism), their age is between 25 and 43 years, while the average age of the sample is 29 years. Half of the respondents have a faculty education degree (basic studies: four-year studies), three respondents completed a master degree, one respondent completed a college (two-year studies), while one respondent gained a high school degree. Regarding the current status of the employment, half of the respondents are part-time employees, two respondents are seasonally employed, two are permanently employed and one is even registered as unemployed.

When it comes to details about the vocational qualifications and years of working tenure, seven out of ten respondents possess higher education (college, faculty or master) in the field of tourism, followed by one respondent with higher education in the field of geography, one respondent in the field of industrial management and one respondent with secondary vocational qualification with duration of four years, while the average working tenure of the respondents is four years.

The following text will provide questions and respondents' answers regarding the business ethics:

Question 1: Did you reach the basic knowledge on business ethics throughout the training for gaining the license of tourist escort (if yes, in which way)?

Person 1: No, I did not reach the basic knowledge on this topic;

Person 2: No, I did not reach the basic knowledge on this subject during the training for gaining the license of tourist escort;

Person 3: Yes, I think I did but in general it all depends on the lecturer and whether that person has appropriate capacity to explain the theory in a clear manner;

Person 4: No, I did not reach the basic knowledge on this subject throughout the training; 
Person 5: No;

Person 6: No;

Person 7: No;

Person 8: Yes, mainly regarding the rights and duties when interacting with the passengers;

Person 9: Yes, on the basis of the course "Guidance in Tourism";

Person 10: Not throughout the training, but I was interested in learning about the rights and duties of the passengers, travel escorts and travel agencies, so I look for these information by myself.

Differences in respondents' answers pointed to inadequate establishment of professional training for preparing the tourist escorts regarding the content of business ethics.

Question 2: Do you think that the license of tourist escort might provide the ethical business behaviour and higher degree of responsibility in business environment? Seven respondents answered with YES, while three respondents answered with $\mathrm{NO}$ on this question.

Question 3: According to your opinion, in which way can the license shape the ethical behaviour of tourist escorts (as a state law document)?

Person 1: The license of tourist escort cannot shape the ethical behaviour; each individual will behave in accordance with personal ethical standards;

Person 2: The license of tourist escort might and must affect the ethical behaviour, in order to provide the highest level of service quality.

Person 3: As a citizen of a specific country, you have personal documents and rights in your country, you are also obliged to act in accordance with the rules prescribed for specific job position;

Person 4: I do not think that the license might shape the ethical behaviour of tourist escorts. I believe that it actually depends on personal moral values of each tourist escort, but also on the rules of appropriate behaviour, prescribed by the travel agency;

Person 5: I consider that the license of tourist escorts could shape their ethical behaviour;

Person 6: I believe that the license cannot shape the ethical behaviour, because we did not have any course regarding the business ethics throughout the licensing program;

Person 7: I consider it all depends on individual values. I also believe that tourist escorts would seriously understand the license as a document only if there is a law with regulations and penalties for unethical behaviour;

Person 8: It is necessary to prescribe appropriate document that will define the penalties for unethical behaviour; 
Person 9: I do not think the license shapes the ethical behaviour of tourist escorts, due to the absence of prescribed sanctions for unethical behaviour;

Person 10: This issue is still not adequately regulated by the law in our country.

Question 4: Are the standards of business ethics transparent to employees in the agency where you are/were angaged in activities of the tourist escort and in which form: a) in written form, b) in verbal form. Seven respondents answered that some domestic travel agencies introduced them with their ethical standards and that these agencies also demanded from tourist escorts to adhere to these rules in the business; two respondents replied that neither one domestic travel agency they work for did not inform them regarding the possession of the ethical code and regarding the necessity to perform in respect to abiding the rules; while only one respondent answered that all domestic agencies, where this respondent was engaged in the position of the tourist escort, possessed the ethical code and introduced their employees with rights and duties regulated by it.

Regarding the form of the ethical code in which it was available and represented to employees by their supervisors, respondents answered in the following way: six of them responded that ethical code was represented in verbal form, while two respondents said that it existed and was available to employees in written form.

Question 5: If the ethical code is represented in the agency, it is usually focused on defining (multiple choices could be selected): the appearance of tourist escorts (primarily rules related to dressing), attitudes towards tourists, attitudes towards work and colleagues, attitudes towards business partners, attitudes towards property, attitudes towards environment, attitudes towards local population, other. Respondents' answers are represented in Table 1.

Table 1: Respondents' answers regarding the terms defined by the ethical code

\begin{tabular}{|l|r|}
\hline \multicolumn{1}{|c|}{ Terms defined by the ethical code } & Number of respondents' answers \\
\hline Attitudes towards tourists & 10 \\
\hline Appearance of tourist escorts & 8 \\
\hline Attitudes towards work and colleagues & 7 \\
\hline Attitudes towards business partners & 4 \\
\hline Attitudes towards property & 3 \\
\hline Attitudes towards local population & 2 \\
\hline Attitudes towards environment & 1 \\
\hline
\end{tabular}

Source: Data obtained through the research conducted in the form of the interviews 
Question 6: Did you have to forward false and incorrect information to tourists in order to protect the interest of the travel agency? Five respondents answered with YES and five respondents answered with NO.

Question 7: What would you expect a tourist to do after the end of the travelling, in a situation of your unprofessional (inappropriate, unpleasant) behaviour towards tourists during that travel?

Person 1: Tourist would not do anything, if he/she is satisfied with the whole service, while in the situation of existing the other objections, he/she would complain to everything;

Person 2: For the start, the tourist would complain to the supervisors of the agency and later he/she would publish his/her complaints on the Internet;

Person 3: Such behaviour is mainly followed by the complaint to the agency regarding the work of the tourist escort;

Person 4: Tourist would appeal to the agency and he/she would also publish his/her dissatisfaction throughout the media (Internet, press);

Person 5: Such behaviour would be followed by the complaint in verbal and written form;

Person 6: Tourist would complain to the agency, while the tourist escort would remain without the daily wage or further engagement in that agency;

Person 7: Tourist would express his/her dissatisfaction directly to the agency and, in some cases, tourist might refuse to pay the unpaid part of the arrangement;

Person 8: Tourist would complain to the agency regarding the work of the tourist escort;

Person 9: Tourist would complain to the agency, which is understandable;

Person 10: Tourist would complain to the agency and he/she would probably not decide to use the services of that agency again.

Question 8: Do you know (maybe you have heard it from your colleagues, or you were manipulated by specific traders...) that while operating the business tasks, some tourist escorts are focused on establishing contact with different traders or caterers and making the agreement with them to direct the travellers/tourists to consume their products/services for some kind of a compensation? Out of the total number of 10 respondents, all of them gave a positive answer.

Question 9: Do you know (maybe you have heard it from your colleagues or you have experienced it by yourself) that some tourist escorts often report lesser number of the passengers than the group actually counts when visiting a museum, gallery, etc. for following reasons: because they are forced to do that by the agency; because some of those sites do not count the exact number of visitor entries for group arrivals? Respondents are equally divided on this question. 
Question 10: Whether the travel agency you work for established some kind of sanctions in the case of dissatisfaction with the engagement of tourist escorts and what does it actually mean?

Person 1: If they are dissatisfied with my work, they would stop my work engagement;

Person 2: If the agency is not satisfied, the management would organize a meeting related to inadequate behaviour of tourist escort. If tourist escort does not change his/her behaviour after the meeting, the agency will not continue with the cooperation;

Person 3: A warning and less frequent engagement of that tourist escort by the agency;

Person 4: I do not know. I have never been in such situation;

Person 5: Decrease in the number of departures and amount of daily wage or even getting fired;

Person 6: Unpaid work;

Person 7: No, it would simply interrupt the cooperation, without any previous suggestions or sanctions;

Person 8: Agencies are not applying sanctions, they are mainly oriented towards informative discussion regarding the mistake and finding the way to correct it;

Person 9: I did not work for such agencies, all the agencies, that I co-operated with, complied the obligations towards tourist escort and, if they are dissatisfied with provided services, they would simply stop working with that tourist escort;

Person 10: Yes, the management of the agency would have a talk with the tourist escort about the causes of dissatisfaction and, in the case of its repetition, the agency will stop cooperating with that tourist escort.

Question 11: Do you feel protected by your employer as the tourist escort in Serbia? Would the agency you work for be on your side in situation of possible complaints or manipulations of the passengers (describe the manner in which your employer would protect you)?

Person 1: They would stand behind me, if I am not guilty;

Person 2: It is debatable, large agencies, tour operators, would protect their tourist escorts, while smaller agencies would not. It is easier to change the employees than losing the passengers;

Person 3: I do not believe that employer will fully protect the tourist escort, perhaps only in the case of groundless complaints of the passengers;

Person 4: The agency was on my side for all groundless complaints;

Person 5: Probably yes, because I did not receive complaints regarding my work until now;

Person 6: The agency would not protect;

Person 7: Only in the case of groundless complaints; 
Person 8: I do not know. I have never been in a similar situation;

Person 9: I believe that the agency would protect me only for the first time;

Person 10: Yes, I feel completely protected by the employer. Long-lasting work resulted in mutual trust. Employer would consider the facts and reasons for complaining, but in general the agency would protect my interest and take side of its employee.

Besides the survey research, as already mentioned, one of the co-authors worked on the position of tourist escort and according to this kind of field research, it could be said that tourist escorts are faced with numerous complaints of tourists, but the most frequent are those related to unfulfilled expectations and promises by the travel agency. It is not unusual for travel agencies to present the services in a different way in comparison with those that tourists really get at a specific destination. In that kind of situations, tourist escorts are first in line for expressing the tourists' dissatisfaction and, as representatives of concrete travel agency, they are responsible for resolving the situation in a manner that is considered as the most acceptable for tourists.

Besides the above-mentioned complaints, tourists often express their dissatisfaction regarding the hospitality and kindness of tourist escorts during the travel and they mostly express their dissatisfaction to travel agency in a written form. For these reasons, tourist escorts are often sanctioned by travel agencies, in the form of their redundant engagement, or even complete termination of engagement and business cooperation. Owners of travel agencies, or more precisely employers of tourist escorts, only in rare occasions are looking from tourist escorts to pay the penalties regarding the guests' complaints.

However, there is a question whether the complaints of tourists regarding the work of tourist escorts are true or they are only the result of tourists' attempt to manipulate in order to achieve some of their goals, mainly focused on gaining the financial prosperity. Certainly, there are tourist escorts who are often unprofessional towards their business and who even behave inappropriately towards tourists during the travel. The main motive of these tourist escorts is financial compensation for their work and they are usually not interested in a fact whether the tourists will receive the service of appropriate quality. On the other hand, there are also tourists who will express their dissatisfaction regarding the quality of working tasks conducted by tourist escorts and submit their complaints to the concrete agency without a realistic reason, in order to gain the arrangement for free of charge or with specific discount. Such cases are frequent and well known in practice and tourists of this profile usually have prepared scenario regarding the way in which they should perform to manipulate the agency.

Also, it is important to highlight the fact that, depending on the gravity of complaints expressed by tourists and in situations when the travel agency fails in resolving these problematic situations, it could be requested from YUTA to 
solve the problem on the basis of its arbitration ${ }^{28}$. YUTA also prescribed specific 'Travel guarantees', focused on the guarantees for quantity and quality of specific services prescribed by the contract with the travel agency. According to these 'YUTA travel guarantees', if the travel agency is closed before starting the travelling, the clients will get their money back within the five days, or they could travel with another travel agency that also poses the aforementioned travel guarantees. Also, if the client arrives at the destination and realizes that the agency did not provide the accommodation on that destination, YUTA could provide help in finding the other accommodation or in organizing the return to the country. However, it is important to bear in mind that all of the agencies that are members of YUTA are not a part of this program, but only those with the visible mark of 'YUTA travel guarantee' in the offices, catalogues and websites. Furthermore, if complaint expressed by tourist is more serious, or more precisely if it violates specific law or includes a commitment of some kind of criminal activity, then judicial authorities will also be involved in resolving the situation ${ }^{29}$.

Thus, employers should work on strengthening the awareness of tourist escorts, but also the tourists in terms of ethical behavior. Representation of the ethical code in tourism could help in developing the awareness of tourism employees on business ethics and ethical behavior. On the other hand, tourists should also be better introduced with general travel conditions.

\section{Conclusion}

Business ethics in the field of conducting the business activities became a necessary process for realizing the purpose and goals of companies, consumers and the public. The basic moral norms and principles of ethics are the starting premises of any successful business cooperation. Global phenomenon - tourism, as a heterogeneous activity, could cause contact between a large number of business entities, and all of these relations could be particularly sensitive, if they are not based on the mentioned principles, especially if we have in mind that tourists are moving from the place of their permanent residence during their travels and that they have high expectations, due to the fact that they invested their free time and the money in travelling. Therefore, implementation of ethical business behaviour needs to be considered as an imperative for activities of tourist escorts, due to the necessity of providing the services in the form of tourism escorting, as the primary segment of tourism.

28 Zeljković David (2018): Pravna zaštita potrošača u turizmu u propisima Republike Srbije (master rad). Novi Sad, Univerzitet u Novom Sadu, Prirodno-matematički fakultet, Departman za geografiju, turizam i hotelijerstvo

29 Official Gazette of Republic of Serbia, 2/2016

Vol. 16, № 2, 2019: 133-154 
Thus, the starting point of this paper was the determination of the attitudes of tourist escorts in terms of the business ethics and its representation while performing the business tasks of tourist escorts in Serbia, as a relatively new and legally recognized profession in this country. Survey research conducted among the licensed travel escorts of Serbia showed that employers (travel agencies) in most cases do not possess the ethical code regarding the acceptable business conduct and that they mainly inform their employees about the principles of business behaviour in verbal form. This data shows that employers are not fully aware of the business ethics and the importance of its application in the business. Also, according to our results, it could be concluded that tourist escorts are not overly informed regarding the principles of business behaviour, as well as that they did not gain the education in the field of ethics during the training and passing the professional exam for licensing. This is pointing to the fact that the professional exam for the tourist escort is not appropriately conceived and comprehensible. However, travel escorts are often faced with different, unpredictable and undesirable situations throughout performing their business tasks, which is the reason why knowledge in the field of behaviour in respect to business ethics could greatly facilitate their work.

According to the opinion of Serbian tourist escorts, existing ethical codes of specific travel agencies are usually focused on attitudes towards tourists in the first place, then the personal appearance of tourist escorts, attitudes towards work and attitudes towards colleagues. Certainly, these claims represent a prerequisite for successful performance of activities and creation of high- quality tourist services, however, it is defeating that attitudes towards business partners, attitudes towards property and, finally, attitudes towards local population and attitudes towards environment are very low, although it is well known that implementation of ethics is of great importance in these areas.

Regarding the unpleasant situations that might arise when performing the business tasks, tourist escorts declared that such situations most often occur due to the negligence and irresponsibility of their supervisors, or they are caused by verbal conflicts with the travellers. Furthermore, most of the tourist escorts in Serbia feel unprotected by their employer. Similarly, the majority of employers do not have a rigorous form of sanctioning the tourist escorts in situations of dissatisfaction with their work, which would result in the license subtraction.

Summarizing the above-mentioned answers of tourist escorts gained through the interviews, it can be concluded that tourist escorts in Serbia do not possess sufficient knowledge in the field of ethical business behaviour and that those ethical business principles are not represented to them during the training for tourist escort licensing or during their work engagement. In order to improve the quality of services of tourist escorting in Serbia, it is primarily necessary to make specific corrections throughout the legislation and to involve business ethics in the course aimed at passing the professional exam for gaining the license of the tourist escort. 


\section{Acknowledgement}

This research is part of the project 'Transformation of geospace in Serbia - past, current problems and solution proposals', approved by the Ministry of Education, Science and Technological Development of Republic of Serbia (registration number: $176020 \mathrm{OI}$ ), as well as the project 'Geotransformation of the area of Vojvodina in the function of regional development', 114-451-2080/201601, approved by the Autonomous Province of Vojvodina, Provincial Secretariat for Higher Education and Scientific-Research Activity (Program 0201) (20162019). Paper is a result of the research work undertaken for the preparation of the master thesis of the candidate Aleksandra Lazarević and the mentor prof. $\mathrm{PhD}$ Aleksandra Dragin.

\section{Literature}

- Dedijer I. (2014): Intervju o licenciranju turističkih pratilaca u Srbiji, Beograd, Ministarstvo trgovine, turizma i telekomunikacija Republike Srbije.

- Donaldson Tom (2003): Taking ethics seriously - A mission now more possible, The Academy of Management Review, 28, 363-366.

- Dornier Raphael, Cothias Vanessa and Loussaief Leila (2011): 'The application of collective ethics charters: The case of French Adventure touroperators', International Business Research, 4(1), 133-144.

- Dragin S. Aleksandra (2011): Turizam i poslovna etika (materijal sa predavanja), Novi Sad, Univerzitet u Novom Sadu, Prirodno-matematički fakultet, Departman za geografiju, turizam i hotelijerstvo.

- Dragin Aleksandra, Jovanović Tamara and Besermenji Snežana (2013): Ethical climate in hospitality facilities in Serbia. Paper presented at the 15th Contemporary Trends in Tourism and Hospitality - CTTH 2013, Novi Sad.

- Dunfee W. Thomas and Black M. Bruce (1996): 'Ethical issues confronting travel agents', Journal of Business Ethics, 15, 207-217.

- Elci Meral, Kitapci Hakan and Erturk Alper (2007): 'Effects of quality culture and corporate ethical value on employee work attitudes and job performance in Turkey: An integrative approach', Total Quality Management, 18(3), 285302.

- Elias Z. Rafik (2005): 'The effect of corporate ethics values on accountants' perception of social responsibility', Journal of Applied Business Research, 21(4), 1-10.

- Gordon Graham and Townsend Claudia (2001): Tourism: Putting ethics into practice, UK Tearfund, Teddington.

- Hansen Fred and Smith Michele (2006): 'The ethics of business strategy', Handbook of Business Strategy, 7(1), 201-206. 
- Kalinić Mina (2012): Poslovna etika i međunarodni hotelski lanac "Hyatt Hotels Corporation" (master rad), Novi Sad, Univerzitet u Novom Sadu, Prirodno-matematički fakultet, Departman za geografiju, turizam i hotelijerstvo.

- Kosar Ljiljana i Rašeta Slobodan (2005): Izazovi kvaliteta: Menadžment kvaliteta u hotelijerstvu, Beograd, Viša hotelijerska škola.

- Krdžić Marko (2014): Poslovna etika na primeru međunarodnog hotelskog lanca "Hilton Worldwide" (master rad), Novi Sad, Univerzitet u Novom Sadu, Prirodno-matematički fakultet, Departman za geografiju, turizam i hotelijerstvo.

- Laksmi Rumkumar Lalitha (2004): 'The effect of quality culture and corporate ethics values on intention to leave and organizational commitment', International Journal of Engineering and Management Sciences, 5(2), 140-145.

- Lazarević Aleksandra (2014): Poslovna etika i turistički pratilac (master rad), Novi Sad, Univerzitet u Novom Sadu, Prirodno-matematički fakultet, Departman za geografiju, turizam i hotelijerstvo.

- MacDougall E. Alexandra, Bagdasarov Zhanna, Johnson F. James and Mumford D. Michael (2015): 'Managing workplace ethics: An extended conceptualization of ethical sense making and the facilitative role of human resources', Personnel and Human Resources Management, 33, 121-189.

- Malloy David Cruise and Fennell A. David (1998): 'Codes of ethics and tourism: An exploratory content analysis', Tourism Management, 19(5), 453461.

- Mijatov Maja, Dragin Aleksandra and Jovanović Tamara (2015): Ethical climate in hotels of Kopaonik. Paper presented at the 16th Contemporary Trends in Tourism and Hospitality, Novi Sad.

- Miller A. Robert (2014): 'Profiles and shadows in business ethics. Moral saints and moral exemplars', Ethical Issues in Organizations, 10, 97-115.

- Ministry of Trade, Tourism and Telecommunications of Republic of Serbia. (2017): Revoked licenses to travel agencies in 2017. (Retreived from: http:// mtt.gov.rs/download/Oduzete\%20licence\%20turisti\%C4\%8Dkim\%20 agencijama\%20dec.\%202017.pdf).

- Mišković Ivana (2012): 'Ethics in providing tourism services by travel agents in Serbia', Turizam, 16(1), 20-28.

- Official Gazette of the Republic of Serbia. (1978): Official Gazette of the Republic of Serbia 10/78. (Retrieved from: http://www.pravnoinformacioni-sistem.rs/SlGlasnikPortal/arhslgl/SGARHSTARO/ numberOverview?numberId=13667).

- Official Gazette of the Republic of Serbia. (1979): Official Gazette of the Republic of Serbia 33/1979. (Retrieved from: http://www.pravnoinformacioni-sistem.rs/SlGlasnikPortal/arhslgl/SGARHSTARO/ numberOverview? numberId=13743). 
- Official Gazette of the Republic of Serbia. (2006): Official Gazette of the Republic of Serbia 1/2006. (Retrieved from: http://www.pravnoinformacioni-sistem.rs/SlGlasnikPortal/arhslgl/SGARHSTARO/ numberOverview? numberId=20910).

- Official Gazette of the Republic of Serbia. (2009): Official Gazette of the Republic of Serbia 36/2009. (Retrieved from: http://www.pravnoinformacioni-sistem.rs/SlGlasnikPortal/arhslgl/SGARHSTARO/ numberOverview?numberId=20603).

- Official Gazette of the Republic of Serbia. (2010): Official Gazette of the Republic of Serbia 40/10. (Retrieved from: http://www.pravnoinformacioni-sistem.rs/SlGlasnikPortal/arhslgl/SGARHSTARO/ numberOverview? numberId=4097).

- Official Gazette of Republic of Serbia. (2016): Official Gazette of Republic of Serbia, 2/2016. (Retrieved from: https://www.pravno-informacioni-sistem. rs/SlGlasnikPortal/reg/viewAct/0a2b11bc-df99-4efb-85ae-dc2ef09249f1).

- Prelić Milena (2012): Poslovna etika i turistički vodič (master rad). Novi Sad, Univerzitet u Novom Sadu, Prirodno-matematički fakultet, Departman za geografiju, turizam i hotelijerstvo.

- Ristić Dušan (2004): Osnovi menadžmenta, Novi Sad, Fakultet za menadžment.

- Robertson J. Christopher and Athanassiou Nicholas (2009): 'Exploring business ethics research in the context of international business', Management Research News, 32(12), 1130-1146.

- Serwinek J. Paul (1992): 'Demographic and related differences in ethical views among small businesses', Journal of Business Ethics, 11, 555-566.

- Simat Karolina i Dragin Aleksandra (2012): 'Poslovna etika - element uspešnog poslovanja turističkih agencija', Zbornik radova Departmana za geografiju, turizam i hotelijerstvo, 41, 297-309.

- Simat Karolina, Dragin Aleksandra and Dragićević Vanja (2012): The institutionalization of business ethics of travel agencies in Serbia, 'Turizam', 16(3), 113-123.

- Sims L. Randi and Keon L. Thomas (1997): 'Ethical work climate as a factor in the development of person-organization fit', Journal of Business Ethics, 16, 1095-1105.

- Smith L. Patricia and Oakley III F. Ellwood (1994): 'A study of the ethical values of metropolitan and nonmetropolitan small business owners', Journal of Small Business Management, 32(4), 17.

- Stark Andrew (1992): 'What's the matter with business ethics?' Harvard Business Review, 71 (3), 38-48.

- Štetić Snežana i Dragićević Vanja (2011): 'Evaluacija turističkih agencija u Srbiji', Ekonomske teme, 1, 71-81. 
- Stevanović Sonja (2014): Poslovna etika i međunarodni hotelski lanac "Melia hotels international" (master rad), Novi Sad, Univerzitet u Novom Sadu, Prirodno-matematički fakultet, Departman za geografiju, turizam i hotelijerstvo.

- Stevens Betsy (2001). 'Hospitality ethics: Responses from human resource directors and students to seven ethical scenarios', Journal of Business Ethics, 30, 233-242.

- Subotić Dragan (2009): Korporativna poslovna etika: Vrednosti - načela modeli (Knjiga 1). Beograd, Primenjena korporativna poslovna etika.

- Šuleić Marija, Dragin Aleksandra and Dragićević Vanja (2014): 'Business ethics of tour operators - The case study of TUI', Turizam, 18(4), 154-165.

- Šuleić Marija, Dragin Aleksandra and Dragićević Vanja (2015): The relationship of a foreign tour operator in Serbia towards tourists based on the example of TUI, 'Turizam', 19(1), 1-12.

- Trevino K. Linda (1992): 'Moral reasoning and business ethics: Implications for research, education and management', Journal of Business Ethics, 11, 445459.

- Trevino K. Linda and Nelson A. Katherine (1999): Managing business ethics: Straight talk about how to do it right, New York, John Wiley \& Sons Inc.

- Valentine Sean and Barnett Tim (2002): 'Ethics codes and sales professionals' perceptions of their organizations' ethical values', Journal of Business Ethics, 40(3), 191-200.

- Warren C. Richard (2011): 'Are we making progress in international business ethics?' Humanomics, 27(3), 212-224.

- Weeks A. William, Loe W. Terry, Chonko B. Lawrence and Wakefield Kirk (2004): 'The effect of perceived ethical climate on the search for sales force excellence', Journal of Personal Selling \& Sales Management, 24, 199-214.

- World Tourism Organization - UNWTO. (1999): Global code of ethics for tourism. (Retrived from: http://ethics.unwto.org/sites/all/files/docpdf/serbia. pdf).

- Zeljković David (2018): Pravna zaštita potrošača u turizmu u propisima Republike Srbije (master rad). Novi Sad, Univerzitet u Novom Sadu, Prirodnomatematički fakultet, Departman za geografiju, turizam i hotelijerstvo 


\section{TURISTIČKI PRATILAC I POSLOVNA ETIKA}

Ovaj rad se bavi problematikom razvoja poslovne etike i profesije turistički pratilac. Polazna hipoteza ovog istraživanja je da poslovna etika u Srbiji nije dovoljno uređena, te da turistički pratioci u tom segmentu nisu još uvek adekvatno edukovani, odnosno da čitava profesija nije u dovoljnoj meri uređena i zaštićena. Za prikupljanje podataka korišćene su istorijska metoda i terensko istraživanje (rad koautora kao turistički pratilac) i anketno istraživanje. Prilikom obrade podataka i interpretacije rezultata upotrebljene su deskriptivna metoda, statistička, komparativna metoda i analitičko-sintetička metoda.

Ključne reči: turistički pratilac, Srbija, turizam, poslovna etika 